\title{
Destination Image of Antalya from the Perspectives of Tourists Staying in Hospitality Establishments with the Concept of Halal Tourism
}

\author{
YenalYağmur \\ Siirt University, Siirt, Turkey \\ Akın Aksu \\ Akdeniz University, Antalya, Turkey
}

Received: 1July 2020.Revision received: 23August 2020. Accepted: 10 October 2020

\begin{abstract}
The study's primary purpose is to reveal the destination image evaluations of Antalya by the tourists staying with the concept of halal tourism with the proposed model. In this context, the study was designed as survey-based quantitative research and was carried out on 660 tourists selected by a simple random sampling method in 6 hotels in Antalya destination. As a result of the structural equation modelling analyses, it was determined that the cognitive images of the tourists staying in hotels with the concept of halal tourism affected tourist satisfaction positively. In contrast, their effective images did not significantly impact tourist satisfaction, and that their effective images affected intention to recommend positively while their cognitive images influenced it negatively. Besides, it was found that both cognitive and affective image dimensions did not significantly affect intention to revisit. Furthermore, the results of the analyses indicated that cognitive images of the tourists positively affected their affective images and that tourist satisfaction had a positive impact on their intention to recommend and intention to revisit. According to the research results, it was determined that the cognitive image is a key element for the tourists staying in the halal concept to evaluate Antalya's destination. In this regard, it is evident that public policymakers and hotel managers should formulate their policies and strategies, taking into account the results of the research, as well as implementing policies and practices aimed at increasing the affective evaluations of tourists, which are more important than the cognitive evaluations of tourists in Antalya destination. Finally, it is believed that the study will reveal important practical implications in the context of developing policies and strategies for the managers of the hotels with the concept of halal tourism and for local authorities in the destination where these hotels are located by determining the destination image evaluations of tourists and revealing the relationship between destination image, tourist satisfaction and behavioural intentions.
\end{abstract}

Key Words:Halal tourism, destination image, Islamic marketing, Islamic hospitality, Antalya.

JEL Classification:Z31, Z33.

Reference: Yağmur, Y., Aksu, A. (2020). Destination Image of Antalya from the Perspectives of Tourists Staying in Hospitality Establishments with the Concept of Halal Tourism. Journal of Tourism and Services,21(11), 103-128. doi:10.29036/jots.v11i21.168

\section{Introduction}

Halal tourism is considered to be a newly developing concept and a market with a great potential. In this context, cultural and social activities in the tourism destination are regarded as important issues to be taken into consideration by tourism management organizations to create a halal friendly environment and image in order to be able to get ahead of their competitors in the halal tourism market 


\section{JOURNAL OF TOURISM AND SERVICES}

Issue 21, volume 11, ISSN 1804-5650 (Online)

www.jots.cz

(Han et al., 2019). It has been pointed out recently that Muslim consumers have become sensitive about consuming products and services that comply with Islamic law and that halal awareness among Muslims and the availability of halal options among the options currently offered has increased the selection of halal products for their needs (Battour\& Ismail, 2016). In the light of this information, since the concept is a key element for destination development (Font, 1997) and a strategic tool responsible for positioning the destination (Echtner\&Richi, 1993), it is vital for countries at macro level and for hospitality businesses in Turkey, where the competition is very intense, at micro level to determine the images of the tourists in the destinations where the halal concept is practiced to get a share from the halal market, which has a great trade volume.

Destination image is considered to be a key factor in influencing purchase behaviour (Rodrigues et al., 2011), increasing the likelihood of visiting destinations and making destination attributes tangible (Tasc1\& Gartner, 2007, p.419), influencing behavioural intentions (Zhang et al., 2014, p.220; Xia et al., 2018, p.259), creating tourist or consumer loyalty (Chen \& Phou, 2013, p.269), improving expectations (Kastenholz, 2010, p.314), differentiating destinations (Baloglu et al., 2015, p.1058; Atadil et al., 2017, p.39), building strong brands (Tasc1\& Gartner , 2007, p.419) and promoting competitiveness (Rodrigues et al., 2011, p.100). Although all these benefits of destination image play a vital role for local policy makers and hotels that apply halal concept, which is a very newly developing concept in Turkey, there is no research in the literature that has been conducted to determine the destination image evaluations of tourists accommodating in hotels with this concept. In this regard, it can be stated that this is an original research, and the objectives of the study are as follows: a) the main purpose of the study is to reveal the images of the tourists staying in hotels with the concept of halal tourism for the destination of Antalya and to reveal the relationships between the variables in the proposed model, and b) the objectives of the study are to provide practical evidence to help local administrators, policy makers, and hotel managers take the lead in intense competition and get more share from the halal tourism market, and c) to develop and enrich the literature by filling this gap in the field of halal tourism, which is still in its infancy (Prayag, 2020, p.1). There are some reasons for the research to be conducted in Antalya. Antalya is seen as the capital of tourism in Turkey. This is because it is the second most visited city and the most overnight stays for tourists in 2019 (yigm.ktb.gov.tr), as well as there are many hotel businesses (there are 42 halal hotels (Isedak, 2017) and 339 5-star hotels in June 2020) (yigm.ktb.gov.tr/TR-9579/turizmtesisleri.html). However, Antalya ranks 12th in 2019 in the list of most visited destinations in the world (Euromonitor International, 2019, p.27).

The research structure was created in connection with the main aim of the research. The following section provides an overview of halal tourism and destination image. In the method part, besides presenting models and hypotheses, data collection procedures, sampling characteristics and variables are described. In the results section, analyzes were carried out and hypotheses were tested. Discussion and conclusion sections are given after presenting the results of the study. Ultimately, the limitations and implications of the research are outlined.

\section{Literature review}

\subsection{Halal tourism}

The population of the Islamic world is very large (Latif et al., 2014, p.87), and the growing commercial interest in Muslim consumers increases the size, growth and prosperity of the population (Henderson, 2016, p.340). It is estimated that there are 1.8 billion people who call themselves Muslims, making up $24.1 \%$ of the world population, which is 7.2 billion as of 2015 . More than $61 \%$ of Muslims live in the Asia-Pacific region and 20\% in the Middle East and in Africa. In 2060, the world's population is projected to be approximately 9.6 billion people and the Muslim population (representing 31.1\%) is estimated to be 2.9 billion people (Pew Research Center, 2017, p.10). In connection with the growing 


\section{JOURNAL OF TOURISM AND SERVICES}

Issue 21, volume 11, ISSN 1804-5650 (Online)

www.jots.cz

Muslim population worldwide, there is a great potential for organizations to get a share of halal products and services in the Muslim market and to do business on this issue (Sahidaet al., 2011). The halal market is regarded as a global market with a volume of USD 580 billion annually in the world trade and is expected to grow by 7 percent per year (Alam\&Sayuti 2011, p.9).

Today, the halal market goes beyond the traditional food industry (Talib et al., 2016, p.463) and also covers areas such as medicinal product (medicine), personal care products, tourism, cosmetics, hygiene products and logistics (Dube et al., 2016, p.127). Halal tourism, an important sub-branch of the halal sector, has gained popularity in recent years. For this reason, although the concept has been applied in many countries and destinations lately, there is no concept that is generally accepted by everyone in the literature as the terminology of the term is quite new in academic literature (Ryan, 2016, p.121). As a matter of fact, when the related literature is examined, it is seen that the terms "Halal Tourism", "Islamic Tourism" or "Muslim-Friendly Tourism" are used by researchers to refer to the tourism products and services that address the needs of Muslim tourists (Yagmuret al., 2019). This confusion in the use of the terms for the concept can also be seen in its definition. The reason why the concept does not have an accepted definition by everyone results from the fact that the concept has a multi-disciplinary nature (Küçüktopuzluet al. 2019) and is defined by considering a different feature of its (Yagmuret al. 2019). Researchers made different definitions considering the various features of the concept. Abral (2017, p.235) has defined halal tourism as a form of religious tourism that practices Islamic teachings anywhere in the world, on the condition that it's done among Muslim consumers. Wheras Haque and Momen (2017, p.154) state that the concept expresses an experience, activity or tolerance which is performed as a travel within the framework of Islamic law, along with the presentation of one or all of the features such as culture, heritage, history, art, lifestyle, economy, health, education and other humanitarian priorities with the Islamic values, Puangniyomet al. (2017, p.196) describes it as the preparation of tour packages and destinations designed according to the needs of Muslims. In addition, Battour and Ismail (2016, p.151) and Tuna (2016, p.261) define it as any tourism activity or object that Muslims are allowed to use or attend in the tourism industry according to Islamic teachings. TSI (Turkish Standards Institution) (2016, p.1) defines the concept as economic, cultural, technical measures and all the work done to attract travellers to a country or a region with excursions organized for Muslims to rest, dress, feed, have fun, see, learn about and at the same time to perform their prayers easily within the Islamic values. Jafari and Scott (2014, p.20) describe the concept as a strategy to promote the encouragement of tourists who will fulfil the requirements of Islamic laws in a way to minimize the socio-cultural effects of tourism in accordance with the principles of sustainability. According to Zulkifliet al., (2011, p.299), halal tourism is any activity compatible with Islam or Islamic principles with airline, hotel, food and tour packages. Razzaq et al., (2016, p.93) define the concept as tourism created jointly by the consumer and the producer in line with the Islam teachings, while Wardiet al., (2018) describe it as any touristic activities performed by Muslims based on Islamic law. Furthermore, Ahmed and Akbaba (2018, p.16) explain the concept of halal tourism as any tourism activity which is permitted in tourism industry considering the Islamic law and teachings and which is carried out by Muslims and non-Muslims without any discrimination in a Muslim and non-Muslim destination. As can be seen from the definitions made, there is no consensus on the definition of the concept. However, although there are definitions made with different perspectives about halal tourism in the body of literature, it is generally considered as a product that meets the needs of Muslim tourists in the tourism industry (Zulkifliet al., 2011; Zailaniet al., 2011; Chaninet al., 2015; Gabdrakhmanovet al., 2016; Musa et al., 2016; Samori et al., 2016; Wilson, 2017).

The halal tourism market is seen as a niche market (Pamukçu and Arpac1, 2016) with an increasing potential with its young demographic structure, as well as one of the highest spending tourism markets in the world. As the halal tourism industry develops and becomes profitable, many Muslim and nonMuslim countries will want to develop their capacity to meet the needs for tourism products, facilities and infrastructures which comply with Islamic law and to take a place in this market (Ahmed and Akbaba, 2018). Thus, many countries such as Turkey, Malaysia, India, Egypt, Dubai, Australia, Spain and Thailand 


\section{JOURNAL OF TOURISM AND SERVICES}

Issue 21, volume 11, ISSN 1804-5650 (Online)

www.jots.cz

that want to get a share of this market carry out various marketing strategies to attract these tourists (Pamukçu and Arpac1, 2016). In this regard, when the year 2018 is evaluated, the most visited non-Muslim countries were Singapore, South Africa, Thailand, United Kingdom, Bosnia and Herzegovina, India, Germany, Australia and Tanzania while the Muslim countries such as the United Arab Emirates, Turkey, Indonesia, Saudi Arabia, Morocco, Jordan, Qatar, Tunisia and Egypt were the most visited destinations (Han et al., 2019). However, some Asian countries such as Malaysia, Indonesia, Turkey and the UAE are seen as the leading players in halal tourism industry (Elaziz and Kurt, 2017) which is of vital importance in Turkey, Malaysia and many other countries trying to attract Muslim tourists from all over the world by presenting services and opportunities compatible with the Muslim belief (Puangniyom, 2017).

\subsection{Destination image}

The concept of the destination image was originally used as an explanatory variable of tourist behaviour, and the emergence of the concept can date back to James Hunt (1971). Destination image is a multidisciplinary field of study as it has many effects and it's found in disciplines like destination image formation, anthropology for human behaviour, sociology, geography, semiotic and tourism, and marketing with the understanding of consumer behaviour, and there are many possible approaches to study this concept (Gallarzaet al., 2002, p.57). The concept of image was studied for many years in disciplines such as social and environmental psychology, marketing and consumer behaviour before it was extensively addressed in tourism research (Stepchenkova\& Mills, 2010, p.577). Despite the fact that the concept is related to tourism marketing, research on tourism destination image faces many difficulties. The first of these difficulties arises from the complexity and multidimensionality of the tourism product (Smith, 1994). The second is that destination marketing requires that the consumer act physically in accordance with the behaviour scenario. Thirdly, there is a great subjectivity in providing tourism services, which causes the image to be confused with impressions about local people, retailers, tourists and employees. The last but most important one is the intangibility of tourism service. In other words, image evaluation is prevented because pre-visit selection and appreciation of the destination before visiting depend on the invisible elements (Gallarzaet al., 2002, p.57).

For nearly forty years, a lot of different concepts in tourism research have been addressed under the label of destination image without a common agreement on how to define or measure them. Though the conceptualizations of this term differ significantly, destination image has a generally-accepted prototype definition which describes it as the mental representation of a destination in an individual's mind (Kock et al., 2016, p.29-30) or a set of attributes that exist in the minds of tourists (e.g. beliefs, feelings and evaluations) for a certain destination (Wang et al., 2018, p.613). However, such prototype understandings are expressed intuitively (Kock et al., 2016, p.29-30). It is also argued that the concept is difficult to conceptualize and measure appropriately (Iordanova-Krasteva, 2013, p.16) due to its vague nature (Kock et al., 2016, p.29-30). Marketing a place as a tourism destination has been of great importance since the 1970s, and at this point the destination image is seen as a sub-component of destination marketing. The studies by Hunt (1975), Crompton (1979) are accepted as the starting point for this research field, and even though there have been a significant number of studies in this field for the last forty years, some authors (Fakeye\& Crompton, 1991; Echtner\& Ritchie, 1991, 2003; Gartner, 1994) state that destination image still lacks a conceptual framework. And as a natural consequence of this uncertainty, there is still no consensus on how to define it (Rodrigues et al, 2011, p.99-100).

Hunt (1975) defines destination image as the impression of people, places, climates and attractions. While Lawson and Baud-Bovy (1977) describe the concept as the expression of all the emotional thoughts, knowledge and prejudice that an individual or a group has about a specific destination, Crompton (1979) expresses it as the sum of impressions, ideas and beliefs about a destination. Gartner (1989) define it as a complex combination of various products and attributes, and Fakeye and Crompton (1991) suggest that it is the cumulative ideas, expectations, impressions, beliefs 


\section{JOURNAL OF TOURISM AND SERVICES}

Issue 21, volume 11, ISSN 1804-5650 (Online)

www.jots.cz

and emotions about a destination. Echtner and Ritchie (1993) view it as a multi-dimensional concept and impression which consists of symbolic concrete attributes. Kotler (1994, p.223) asserts that destination image is the clear results of a particular person's beliefs, ideas, feelings, expectations and impressions about a destination. Milman and Pizam (1995, p.21) explain the concept as the characteristics of image which creates the tourism experience or the compilation of its individual items. Similarly, Baloglu and Brinberg (1997, p.11) define it as the sum of people's beliefs, ideas and impressions with respect to a destination or place. In addition, Sonmez and Sirakaya (2002, p.185) claim that it is a form of mental perception of the basic symbolic attitude and compatibility that is possessed by the members of a group while Bigneet al. (2001, p.607) regard destination image as a subjective interpretation of reality made by the tourist. According to Beerli and Martin (2004), destination image consists of opinions about natural and cultural sources, tourism and leisure infrastructure, atmosphere, social environment, sand and sun, knowledge, relaxation, entertainment and prestige. Finally, Tasciet al. (2007, p.200) define the concept as an interactive system of opinions, ideas, feelings, visualizations and intentions related to a destination, and Alaeddinoglu\& Can (2010, p.341) describe it as perceptions, beliefs and attitudes about the selected attributes of a particular destination. When these descriptions are examined, it can be put forward that there is a consensus on the definition of destination image which is described as the sum of beliefs and impressions obtained from a variety of information sources over time about a destination although there are many definitions made by a variety of researchers and authors about destination image. Also, some researchers and authors (Gallarzaet al. 2002; Li \& Vogelsong, 2006; Milman\&Pizam, 1995) had a consensus on the fact that destination image cannot remain unchanged, so it is in constant change (Xu et al., 2018, p.4). In other words, destination image is not static but dynamic (Jeong\& Holland, 2002, p.503). Thus, it can be asserted that the dynamic nature of destination image will make it more difficult to define and measure the concept.

Hunt (1975) emphasizes that the images of the destinations and their meanings are one of the major factors leading to increased demand, and claims that destination image has an effect on consumer behaviour. In addition to having a positive impact during travel, a better image increases the likelihood of choosing a destination and also leads to more positive post-travel behaviour such as increased loyalty, measured by intention to visit and future recommendation. It is also emphasized that the positive image of a destination is important for attracting new tourists through recommendation and word-of-mouth (Mano \& Costa, 2015). As a matter of fact, Gartner (1994) stated that the image of the destination is an effective tool in advertising, promotion or similar marketing activities. It is believed that image affects consumer decisions and represents the destination due to the fact that destinations are intangible tourism products and there is limited amount of information about destinations before travel (Tasci\& Gartner, 2007, p.419).Furthermore, image plays an essential role in visitor satisfaction during the trip. The more positive the images and perceptions of the visitors after the trip, the more likely they are to revisit the destination and to recommended it to others by creating a positive impact on destination loyalty (Zhang et al., 2014; Mano \& Costa, 2015). In addition to various sources of information and publicity, the image formed by the personal experience and the direct experience of travellers in a place is considered to be the impetus behind the evaluation and selection of a destination and plays a central role in the evaluation of a destination (Papadimitriou et al., 2015, p.302). What is more, destination image is stated to be of vital importance since it differentiates the destinations in a competitive environment and it occupies a suitable place in the minds of potential visitors by developing a positive and memorable image (Balogluet al., 2015, p.1058). Moreover, it is argued that destination image is the main determinant in predicting tourists' perceived destination image, satisfaction, and intention to participate in future activities (Xia et al., 2018, p.259) by suggesting that destination image plays an important role in establishing tourist loyalty, and that if the aim is to be permanent, the relations with tourists should be proactively addressed and that it constitutes a crucial part of strong brands (Chen \& Phou, 2013, p.269-270).

Despite the extensive literature on the conceptualization and measurement of destination image, there are inconsistencies about which components constitute the construct of destination image. Some 


\section{JOURNAL OF TOURISM AND SERVICES}

Issue 21, volume 11, ISSN 1804-5650 (Online)

www.jots.cz

research focuses only on the cognitive dimension (Echtner\& Ritchie, 1991; Prayag, 2009), which only consists of the belief and information about the physical attributes of a destination, whereas others (Baloglu\& McCleary, 1999; Hosanyet al., 2007) are focused on the affective aspect of the brand image which includes feelings, excitement and emotions about the destination. Gartner (1994) puts forward that destination image is comprised of three main components: cognitive, affective and conative. Perceived destination image which is constituted by these three components stated by Gartner is indicated to represent the process of psychological and subjective perception. Most of the tourism researchers, on the other hand, agree that destination image is composed of at least two components as cognitive image and affective image (Atadilet al., 2017) or it is a multi-dimensional construct including two main dimensions (Hosanyet al., 2006). These dimensions are cognitive evaluation and affective evaluation related to a destination (Baloglu\& McCleary, 1999). Kaplan (1991) maintains that cognitive and affective attributes are integrated components of the human mental framework during parallel and social judgment. Cognitive and affective dimensions make up the overall image of a certain destination. While cognitive evaluation is determined by the belief and knowledge about a place, affective evaluation is related to feelings for the destination (Baloglu\& McCleary, 1999). In cognitive evaluation, a tourist evaluates a place with the best information it has in terms of the objective characteristics of the destination. This means that the more information the tourist has about the positive attributes of a destination, the more reliable his cognitive evaluation is. Affective evaluation can be expressed as the sum of the affective evaluations of a tourist regarding the destination attributes. In this sense, the more attractive the destination attributes are to the tourist, the better the tourist's evaluation will be. In addition, Beerli\& Martin (2004) suggest that there is a theoretical consensus in the literature that cognitive image is the antecedent of affective image, while different factors are subject to overall assessment other than cognitive and affective evaluations. Besides, Beerli\& Martin (2004) assert that affective and cognitive images together lead to an overall image resulting in a positive or negative image about a destination. And in response to this, some researchers in the field (Baloglu\& Love, 2005; Baloglu\& McCleary, 1999; Gartner, 1994) report that overall assessment may be similar to or different from cognitive and affective evaluation. As the overall image and its components (cognitive and affective images) may be different, it is suggested that each component and the overall image should be measured separately to better understand the relationships between them (Sahin\&Baloglu, 2011). On the other hand, Stern, Krakover (1993) and Baloglu and McCleary (1999) have determined that cognitive and affective evaluations have a direct and positive correlation with the overall image (Sahin\&Baloglu, 2011, p.72). In the literature, it is observed that there is no consensus about what dimensions the destination image has related to its dimensions. In this context, the two-dimensional (cognitive and affective) destination image scale developed by Baloglu and Mangaloglu (2001) was preferred in the present study because it was used in many studies (Stylidiset al., 2017; Chen \& Tsai, 2007; Lee et al., 2005; Baloglu\& McCleary, 1999).

\section{Methods}

\subsection{Sample}

Halal tourism is a very new concept and has recently begun to develop in Turkey. Because there are no hotels in Turkey with halal certification that is received from the Turkish Standards Institute (TSI) or from an internationally accredited organization (Isedak 2017, p.54), hotels that call themselves halal or Islamic hotels were included in the study.Quantitative research was preferred in this study due to the fact that the concept of halal tourism is a very new concept, this field is very suitable for qualitative research, but the results cannot be generalized, and there are insufficient quantitative studies in the body of literature. Within this context, as reported in Isedak (2017, p.54), today there are approximately 140 hotel establishments which define themselves as halal or Islamic, from coastal resorts to green resorts and 


\section{JOURNAL OF TOURISM AND SERVICES}

Issue 21, volume 11, ISSN 1804-5650 (Online)

www.jots.cz

thermal hotels, whereas there were fewer than 10 hotels that described themselves as halal in the early 2000s. To be able to contact with the hotels that call themselves halal or Islamic and to determine the research universe, websites such as islamitatilyerler.net, helalboking.com, consazakarotelim.com and halaltrip.com were examined, and the total number of hotels with halal concept in the destination of Antalya was identified to be 42.Permission was granted to administer the questionnaires in 20 hotels that were determined via simple random sampling method by contacting the managers of several hotels, both via e-mail, and through the agency of the thesis advisor and members of the thesis monitoring committee. Accordingly, necessary permissions were taken from four five-star hotels and one four-star hotel in Alanya region and from one five-star hotel in Kaş region. The questionnaires were administered by pollsters and front desk personnel in the hotels that gave permission. In the research, the names of the hotels were coded using the letters from A to F, as requested by the hotels and participants. The questionnaires were administered between 1 July and 30 August 2018, and a total of 700 questionnaires were obtained from the hotels. While entering the data into the package program (SPSS 22.0) for data analysis, 40 questionnaires were excluded from the analysis due to the fact that they were incomplete, and the remaining 660 questionnaires were used for data analysis.

\subsection{Instruments}

The questionnaire used in the study comprised two sections. The first section included the destination image scale developed by Baloglu and Mangaloglu (2001) and the three outcomes (satisfaction, intention to recommend and continued intention to use) on the halal items scale developed by Olya and Al-ainsi (2018). The halal items scale consisting of nine statements is a five-point Likert scale ( $1=$ strongly disagree $-5=$ strongly agree). The destination image scale consisted of 18 questions. On the scale, 14 items (cognitive image) were built as a five-point Likert type $(1=$ strongly disagree $-5=$ strongly agree) and 4 items (affective image) were bipolar. It is understood that the destination image scale is accepted and used by many researchers (Stylidiset al., 2017; Chen, Tsai, 2007; Lee et al., 2005; Baloglu\& McCleary, 1999). However, the validity of the halal items scale developed by Olya and Al-ainsi (2018) could not be tested because the concept of halal tourism is a newly developing area and research in this area is still in its infancy. The second section consists of demographic variables (gender, marital status, age, educational background, monthly income) and statements that aim to determine the travel companions of the tourists, what information source they used when planning their trip and their nationality.

The questionnaires were administered both in English and Turkish. The questionnaire was translated into Turkish, so the Turkish version of the questionnaire was designed. A total of five faculty members who worked at Akdeniz University Faculty of Tourism Expert were consulted for expert opinions in order to evaluate whether the statements were clear and complied with Turkish. In addition, a native English-speaking instructor was asked to translate the questionnaire into English. In line with the feedback of the instructor, final corrections were made on the questionnaire and it was released for pilot study. The reason why a pilot study was conducted is to measure the reliability of the questionnaire and the clarity of the statements in the questionnaire. As a result of the pilot test, a total of 60 questionnaires were obtained, and after final corrections were made, the questionnaire was ready to be administered.

The normality test of the scale was carried out in order to perform the analyzes. Table 1 demonstrates the mean, standard deviation and skewness values of the statements and dimensions used in the study. One of the assumptions required to use the structural equation modelling is that it has a normal distribution. It was determined that the statements in the questionnaire and the dimensions had normal distribution values that were between -1.03 and -0.40 . Since the skewness values of the overall scales and the sub-dimensions ranged between +2 and -2 values, it can be suggested that they were 


\section{JOURNAL OF TOURISM AND SERVICES}

Issue 21, volume 11, ISSN 1804-5650 (Online)

www.jots.cz

normally distributed (Karagöz, 2017, p.458). Standard deviation and skewness values of the statements and dimensions used in the study are as follows:

Table 1.The mean, standard deviation, and skewness values of the destination image scale for Antalya and the three outputs

\begin{tabular}{|c|c|c|c|}
\hline Items & Mean & $\begin{array}{c}\text { Standard } \\
\text { Deviation }\end{array}$ & Skewness \\
\hline Cognitive Image & 3.74 & 0.63 & -0.67 \\
\hline Standard Hygiene and Cleanliness & 3.80 & 1.04 & -0.84 \\
\hline Quality of Infrastructure & 3.70 & 0.92 & -0.48 \\
\hline Personal Safety & 3.84 & 0.89 & -0.62 \\
\hline Good Nightlife and Entertainment & 3.83 & 0.95 & -0.48 \\
\hline Suitable Accommodations & 3.89 & 0.95 & -0.55 \\
\hline Appealing Local Food (Cuisine) & 3.71 & 1.05 & -0.55 \\
\hline Great Beaches/Water Sports & 3.80 & 1.00 & -0.70 \\
\hline Interesting and Friendly People & 3.65 & 1.01 & -0.45 \\
\hline Interesting Cultural Attractions & 3.73 & 1.03 & -0.53 \\
\hline Interesting Historical Attractions & 3.71 & 1.01 & -0.54 \\
\hline Beautiful Scenery/Natural Attractions & 3.80 & 1.01 & -0.67 \\
\hline Unpolluted/Unspoiled Environment & 3.44 & 1.13 & -0.40 \\
\hline Good Climate & 3.73 & 1.04 & -0.72 \\
\hline Good value for money & 3.74 & 1.08 & -0.71 \\
\hline Affective Image & 3.79 & 0.90 & -0.81 \\
\hline Unpleasant - Pleasant & 3.80 & 1.12 & -0.72 \\
\hline Sleepy - Arousing & 3.84 & 1.07 & -0.74 \\
\hline Gloomy - Exciting & 3.80 & 1.12 & -0.67 \\
\hline Distressing - Relaxing & 3.72 & 1.13 & -0.67 \\
\hline Intention to Recommend & 3.93 & 0.93 & -0.80 \\
\hline I will recommend halal items to other tourists. & 3.88 & 1.07 & -0.78 \\
\hline I will say positive things about halal items to other people. & 3.97 & 0.99 & -0.88 \\
\hline I will encourage friends and relatives to consume halal items. & 3.95 & 1.02 & -0.83 \\
\hline Continued Intention to Use (CIU) & 4.00 & 0.93 & -0.88 \\
\hline I intend to continue consuming halal items in the future. & 4.00 & 1.04 & -0.90 \\
\hline I will continue consuming halal items as much as possible in the future. & 4.05 & 1.01 & -0.97 \\
\hline I will re-consider halal items as a priority in my needs in the future. & 3.96 & 1.01 & -0.87 \\
\hline Satisfaction & 4.03 & 0.93 & -0.94 \\
\hline I am pleased to consume halal items. & 4.03 & 1.03 & -1.03 \\
\hline I think that consuming halal items is a good idea. & 4.03 & 1.01 & -1.02 \\
\hline $\begin{array}{l}\text { I am satisfied with my overall experience of being a consumer of halal } \\
\text { items. }\end{array}$ & 4.04 & 1.00 & -0.98 \\
\hline
\end{tabular}

$\mathrm{n}=660 ; 1$ means strongly disagree and 5 means strongly agree on the questionnaire.

Source: Authors' processing

\subsection{Data analysis}

In the study, the data was analyzed through SPSS 22.0 (Descriptive statistics) and Amos 22 (Structural equation modelling) programs. Structural equation modelling (SEM) is a multivariate technique that can be described as the combination of factor analysis and path analysis. Structural equation modelling is defined as a statistical technique that allows the researcher to simultaneously examine a series of dependence relationships between endogenous and exogenous variables. In structural equation modelling, the distinction between endogenous and exogenous variables should be emphasized. According to Pedhazur (1997), the variability in an exogenous variable is claimed to be determined by causes other than the model under consideration. On the other hand, an endogenous variable is defined 


\section{JOURNAL OF TOURISM AND SERVICES}

Issue 21, volume 11, ISSN 1804-5650 (Online)

www.jots.cz

as the variation explained by the endogenous variables of the model and other endogenous variables. The benefits of using structural equation modelling can be listed as follows:

- It provides a method through which multiple relationships can be simultaneously explained.

- It allows the representation of unobserved (latent) concepts in the analysis of dependence relationships.

- Measurement error is calculated in estimation methods, which contributes to the improvement of statistical estimates (Ho, 2014, p.421-422).

Schreiber et al. (2006, p.326) suggest that the sample size must be at least 10 times the number of the variables used in the study in order to perform many analyses, while a sample size between 30 and 500 is stated to be sufficient for many studies by Altunış1ket al., (2012, p.137). In addition, it has been put forward that the sample size should be at least 200 for structural equation modelling studies (Garver and Mantzer, 1999, p.42). The number of samples used in the present study is 660, which meets the sample size required for structural equation modelling. As a result of the reliability analysis of the scale consisting of 27 questions, the Cronbach Alpha value was found to be 0.881 . Finally, the visual for the proposed model and the research problems examined in this context are given as follows:

Figure 1.The proposed model

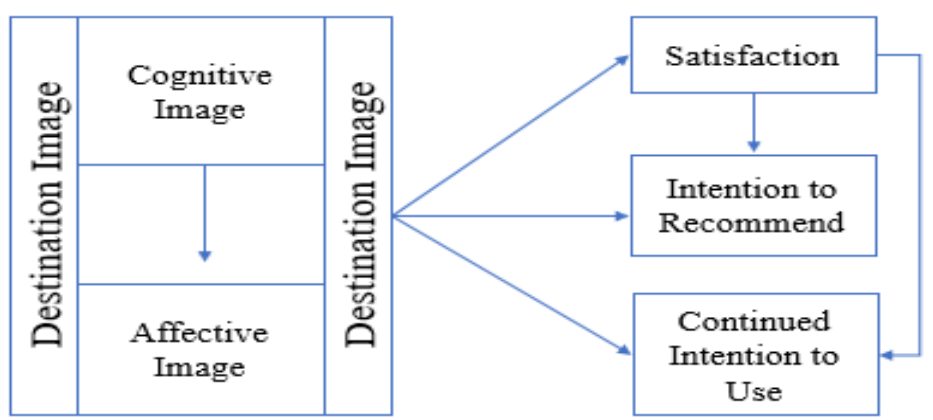

Note: The relationship between cognitive and affective image dimensions and the three outputs was examined. Source: Authors' processing

H1: Cognitive destination image of tourists staying in halal concept hospitality establishments has a positive impact on their intention to revisit.

H2: Cognitive destination image of tourists staying in halal concept hospitality establishments has a positive impact on their intention to recommend.

H3: Cognitive destination image positively affects the satisfaction of tourists staying in halal concept hospitality establishments.

H4: Affective destination image of tourists staying in halal concept hospitality establishments has a positive impact on their intention to revisit.

H5: Affective destination image of tourists staying in halal concept hospitality establishments has a positive impact on their intention to recommend.

H6: Affective destination image positively affects the satisfaction of tourists staying in halal concept hospitality establishments.

H7: Cognitive destination image of tourists staying in halal concept hospitality establishments has a positive impact on their affective destination image.

H8: Satisfaction of tourists staying in halal concept hospitality establishments positively affects their intention to recommend.

H9: Satisfaction of tourists staying in halal concept hospitality establishments positively affects their intention to revisit. 
JOURNAL OF TOURISM AND SERVICES

Issue 21, volume 11, ISSN 1804-5650 (Online)

www.jots.cz

\section{Results}

Demographic variables of the participants are presented in Table 2.

Table 2.Demographic variables

\begin{tabular}{|c|c|c|c|c|}
\hline & Particip & & & \\
\hline Independent Variables & Group & $\mathbf{n}$ & $\%$ & $\begin{array}{c}\text { Percentage of } \\
\text { those who said } \\
\text { yes }\end{array}$ \\
\hline & Female & 336 & 50.9 & \\
\hline Gender & Male & 324 & 49.1 & \\
\hline & Total & 660 & 100.0 & \\
\hline & Married & 398 & 60.3 & \\
\hline Marital Status & Single & 262 & 39.7 & \\
\hline & Total & 660 & 100.0 & \\
\hline & $18-27$ & 193 & 29.2 & \\
\hline & $28-37$ & 255 & 38.6 & \\
\hline Age & $38-47$ & 153 & 23.2 & \\
\hline & 48 and over & 59 & 9.0 & \\
\hline & Total & 660 & 100.0 & \\
\hline & Primary school & 71 & 10.8 & \\
\hline & High school & 274 & 41.5 & \\
\hline Educational background & University & 237 & 35.9 & \\
\hline & Master's/Doctoral degree & 78 & 11.8 & \\
\hline & Total & 660 & 100.0 & \\
\hline & $0-1000$ Euro & 280 & 42.4 & \\
\hline & $1001-2000$ Euro & 228 & 34.5 & \\
\hline & $2001-3000$ Euro & 94 & 14.2 & \\
\hline Income (Monthly) & $3001-4000$ Euro & 49 & 7.4 & \\
\hline & $\begin{array}{l}4001-5000 \text { and } 5001 \text { Euro } \\
\text { and above }\end{array}$ & 9 & 1.5 & \\
\hline & Total & 660 & 100.0 & \\
\hline & Alone & 52 & 7.9 & \\
\hline & Spouse/Partner & 233 & 35.3 & \\
\hline Travel Companion of the tourists & Family/Relative & 242 & 36.7 & \\
\hline & Friends & 102 & 15.5 & \\
\hline & Tour & 31 & 4.7 & \\
\hline & Total & 660 & 100.0 & \\
\hline & Travel Agency & 214 & 19.4 & 32.5 \\
\hline & $\begin{array}{l}\text { Friend/Family } \\
\text { Recommendation }\end{array}$ & 378 & 34.3 & 57.4 \\
\hline $\begin{array}{l}\text { Information Sources used by the } \\
\text { tourists while planning their trip }\end{array}$ & Mass media/Media & 80 & 7.3 & 12.1 \\
\hline & Magazines & 62 & 5.6 & 9.4 \\
\hline & The Internet & 368 & 33.4 & 55.8 \\
\hline & Total & 1102 & 100.0 & 167.2 \\
\hline & German & 18 & 2.7 & \\
\hline & Algerian & 36 & 5.4 & \\
\hline Nationality & British & 28 & 4.2 & \\
\hline tvationamy & Turkish & 552 & 83.6 & \\
\hline & Other & 26 & 4.1 & \\
\hline & Total & 660 & 100.0 & \\
\hline & A & 93 & 14.0 & \\
\hline
\end{tabular}




\section{JOURNAL OF TOURISM AND SERVICES}

Issue 21, volume 11, ISSN 1804-5650 (Online)

www.jots.cz

Table 2.Demographic variables

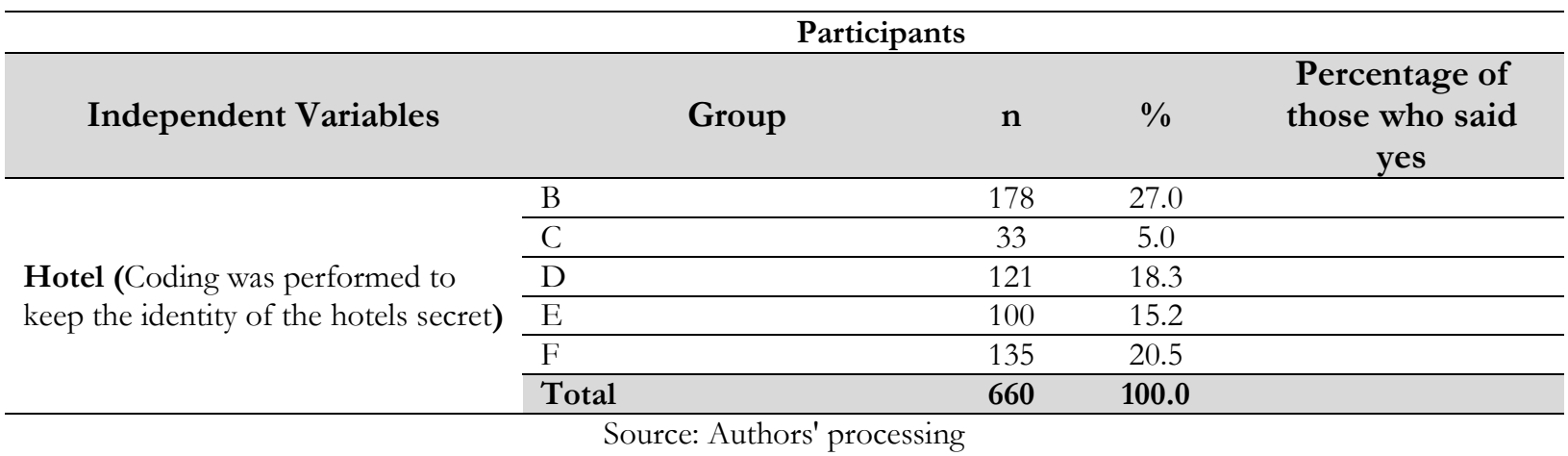

When Table 2 is examined, the findings related to the demographic characteristics of the participants can be explained as follows: A total of 50.9\% $(n=336)$ of the tourists participating in the research were female and $49.1 \%(\mathrm{n}=324)$ were male. In addition, $60.3 \%(\mathrm{n}=398)$ of the participants were married while $39.7 \%(\mathrm{n}=262)$ were single. When the age ranges of the tourists are examined, it can be seen that most of the participants were in the age range of $28-37$ with $38.6 \%$ (255 people). The majority of the participants were high school graduates with $41.5 \%(n=274)$, and $35.9 \%(n=237)$ had a bachelor's degree. Considering the monthly income of the participants, it can be stated that $42.4 \%$ ( $\mathrm{n}$ $=280$ ) of the participants had an income up to 1000 Euros, making up the largest group. The majority of the tourists participating in the study preferred to travel with their family or relatives with $36.7 \%$ ( $\mathrm{n}=$ $242)$ and $35.3 \%(n=233)$ travelled with their spouse or partner. The information sources used by the participants when planning their trips were determined considering the number of 'yes' answers that each tourist gave for the groups. Among the 1102 'yes' answers, the family and friend recommendations group was the highest with $34.3 \%(\mathrm{n}=378)$. When the nationalities of the tourists involved in the study were examined, it was observed that the majority of them were Turkish with $83.6 \%(\mathrm{n}=552)$. Moreover, instead of using the real names of the hotels where the questionnaires were administered, letters (codes) were used because they only allowed the application of the questionnaires on the condition that the names of the hotels would not shared. The vast majority of the participants stayed in Hotel B with $27 \%$ ( $\mathrm{n}=$ $178)$ and in Hotel $\mathrm{F}$ with $20.5 \%(\mathrm{n}=135)$.

Confirmatory factor analysis (CFA) and explanatory factor analysis (EFA) were performed to ensure the construct validity of the scale. The acceptable fit index values in the study were evaluated by considering the fit index values suggested by Hair et al. (2014) and Ho (2014).Firstly, explanatory factor analysis was carried out and the results of the explanatory factor analysis are given in Table 3.

Table 3.Explanatory factor analysis

\begin{tabular}{|c|c|c|c|c|}
\hline Items & $\begin{array}{c}\text { Factor } \\
\text { Loadings }\end{array}$ & $\begin{array}{l}\text { Eigen } \\
\text { Value }\end{array}$ & $\begin{array}{c}\text { Explained } \\
\text { Variance }\end{array}$ & $\begin{array}{c}\text { Cronbach } \\
\text { Alpha }\end{array}$ \\
\hline Cognitive Image & & 5.584 & 25.134 & 0.795 \\
\hline Good Nightlife and Entertainment & 0.610 & & & \\
\hline Suitable Accommodations & 0.691 & & & \\
\hline Appealing Local Food (Cuisine) & 0.765 & & & \\
\hline Great Beaches/Water Sports & 0.595 & & & \\
\hline Interesting and Friendly People & 0.656 & & & \\
\hline Interesting Cultural Attractions & 0.611 & & & \\
\hline Interesting Historical Attractions & 0.662 & & & \\
\hline Beautiful Scenery/Natural Attractions & 0.689 & & & \\
\hline Unpolluted/Unspoiled Environment & 0.673 & & & \\
\hline Good Climate & 0.609 & & & \\
\hline Good value for money & 0.581 & & & \\
\hline
\end{tabular}


JOURNAL OF TOURISM AND SERVICES

Issue 21, volume 11, ISSN 1804-5650 (Online)

www.jots.cz

\begin{tabular}{|c|c|c|c|c|}
\hline Affective Image & & 2.262 & 11.393 & 0.855 \\
\hline Unpleasant - Pleasant & 0.581 & & & \\
\hline Sleepy - Arousing & 0.696 & & & \\
\hline Gloomy - Exciting & 0.717 & & & \\
\hline Distressing - Relaxing & 0.645 & & & \\
\hline Intention to Recommend & & 3.211 & 13.559 & 0.738 \\
\hline I will recommend halal items to other tourists. & 0.666 & & & \\
\hline I will say positive things about halal items to other people. & 0.661 & & & \\
\hline I will encourage friends and relatives to consume halal items. & 0.686 & & & \\
\hline Continued Intention to Use (CIU) & & 2.319 & 8.921 & 0.700 \\
\hline I intend to continue consuming halal items in the future. & 0.756 & & & \\
\hline $\begin{array}{l}\text { I will continue consuming halal items as much as possible in the } \\
\text { future. }\end{array}$ & 0.723 & & & \\
\hline $\begin{array}{l}\text { I will re-consider halal items as a priority in my needs in the } \\
\text { future. }\end{array}$ & 0.737 & & & \\
\hline Satisfaction & & 2.884 & 9.025 & 0.718 \\
\hline I am pleased to consume halal items. & 0.724 & & & \\
\hline I think that consuming halal items is a good idea. & 0.718 & & & \\
\hline $\begin{array}{l}\text { I am satisfied with my overall experience of being a consumer } \\
\text { of halal items. }\end{array}$ & 0.656 & & & \\
\hline
\end{tabular}

The Explanation Rate of Total Variance (\%): 68.032 $\quad$ KMO: 0.914

\begin{tabular}{ll}
\hline Bartlett Sphericity Test: $\mathbf{9 7 6 7 . 8 7 1}$ & p: $\mathbf{0 . 0 0 0}$ \\
\hline & Source: Authors' processing
\end{tabular}

As a result of the explanatory factor analysis, $\mathrm{KMO}$ analysis was performed to test whether the sample size was sufficient and the rate was found to be 0.914 . KMO value is desired to be greater than 0.80 (Sharma, 1996, p.116). The Bartlett sphericity test is used to test whether there are high correlations between at least some of the variables in the correlation matrix. In order to continue the factor analysis, the null hypothesis 'correlation matrix is the unit matrix' needs to be rejected, and if it is rejected, the data set is regarded as suitable for factor analysis (Kalayc1, 2018, p.322). As revealed in Table 3, Bartlett test is significant $(p=0.000)$. As a result of the tests, the scale was found suitable for factor analysis. Factor analysis was performed on 24 statements by using Varimax rotation method. As a result of the factor analysis, the statements' Standard hygiene and cleanliness, Quality of Infrastructure, Personal Security', included in the 'Cognitive Image' dimension were removed from the analysis because they were less than 0.5 (Hair et al., 2009, p.116). The total variance explanation rate was $68.032 \%$, which is above the acceptable rate (Nakip, 2003). Cronbach Alpha values calculated for the internal consistency of the factors ranged between 0.718 and 0.855 , which indicates that the scale is reliable (Hair et al., 2009, p.123).

After explanatory factor analysis, confirmatory factor analysis (CFA) was carried out for the destination image scale and the three outputs, and the results are given as follows:

Table 4.Fit indices obtained in the confirmatory factor analysis

\begin{tabular}{cccc}
\hline Model Fit Indices & Obtained Values & Acceptable Fit values & Good-Excellent Fit Values \\
\hline$\chi^{2} / \mathrm{df}$ & 3.96 & $0<\chi^{2}<5$ & $0<\chi^{2}<3$ \\
\hline RMSA & 0.05 & $0.00 \leq \mathrm{RMSEA} \leq 0.10$ & $0,00 \leq \mathrm{RMSEA} \leq 0.05$ \\
\hline RMR & 0.06 & $0.05<\mathrm{RMR}<0.08$ & $0,00 \leq \mathrm{RMR} \leq 0.05$ \\
\hline SRMR & 0.04 & $0.00<\mathrm{SRMR}<0.08$ & $0,00<\mathrm{SRMR}<0.05$ \\
\hline CFI & 0.94 & $0.90 \leq \mathrm{CFI} \leq 1.0$ & $0,95 \leq \mathrm{CFI} \leq 1.0$ \\
\hline GFI & 0.94 & $0.90 \leq \mathrm{GFI} \leq 1.0$ & $0,95 \leq \mathrm{GFI} \leq 1.0$ \\
\hline NFI & 0.93 & $0.90 \leq \mathrm{NFI} \leq 1.0$ & $0,95 \leq \mathrm{NFI} \leq 1.0$ \\
\hline \multicolumn{4}{c}{ Source: Authors' processing }
\end{tabular}




\section{JOURNAL OF TOURISM AND SERVICES}

Issue 21, volume 11, ISSN 1804-5650 (Online)

www.jots.cz

As a result of the confirmatory factor analysis, the chi-square / degree of freedom $\left(\chi^{2} / \mathrm{df}\right)$ value was found to be 3.96, which means that the overall fit of the model was acceptable. The RMSA (mean square root of approximate errors) value of 0.05 indicates that it had a perfect fit and that the error between the observed and produced matrices was minimal. The RMR (root mean square residual) value of 0.05 shows that it had a very good fit. SRMR (standardized root mean square residual) was also calculated via Amos 22 package program and revealed as 0.04, which indicates an excellent fit. The CFI index is 0.94 and indicates an excellent fit. The GFI (Goodness fit index) value was found to be 0.94, which points out that the index value was within the acceptable limits. The NFI (Normed-fit index) value was determined to be 0.94 , which means that the model had an acceptable fit. When the results of the confirmatory factor analysis are evaluated in general, it can be suggested that the index values were acceptable and had a very good fit. According to these results, the goodness of fit values indicate a good model.

The structural model established to determine the relationship between satisfaction and behavioural intentions dimensions of the destination image scale was tested via path analysis, and the fit index values obtained are illustrated in Table 5. According to Table 5, all of the fit index values are within acceptable limits.

Table 5.The results of the path analysis

\begin{tabular}{|c|c|c|c|c|}
\hline Path & $\begin{array}{c}\text { Standardized Regression } \\
\text { Coefficients }\end{array}$ & $\begin{array}{l}\text { Standard } \\
\text { Error }\end{array}$ & $\mathbf{t}$ & $\mathrm{p}$ \\
\hline Cognitive Image $==>$ Affective Image & 0.387 & 0.057 & 7.133 & $0.003 *$ \\
\hline Cognitive Image $==>$ Satisfaction & 0.507 & 0.078 & 9.422 & $0.006 *$ \\
\hline Affective Image $==>$ Satisfaction & 0.058 & 0.061 & 1.312 & 0.190 \\
\hline $\begin{array}{l}\text { Cognitive Image }==>\text { Intention to } \\
\text { Recommend }\end{array}$ & -0.084 & 0.062 & -2.010 & 0.044* \\
\hline $\begin{array}{l}\text { Affective Image }==>\text { Intention to } \\
\text { Recommend }\end{array}$ & 0.097 & 0.051 & 2.728 & $0.008^{*}$ \\
\hline $\begin{array}{l}\text { Cognitive Image }==>\text { Continued } \\
\text { Intention to Use (CIU) }\end{array}$ & -0.010 & 0.045 & -0.304 & 0.761 \\
\hline $\begin{array}{l}\text { Affective Image }==>\text { Continued } \\
\text { Intention to Use (CIU) }\end{array}$ & 0.039 & 0.036 & 1.434 & 0.152 \\
\hline $\begin{array}{l}\text { Satisfaction }==>\text { Continued Intention to } \\
\text { Use }(\mathrm{CIU})\end{array}$ & 0.939 & 0.039 & 23.459 & $0.001 *$ \\
\hline $\begin{array}{l}\text { Satisfaction }==>\text { Intention to } \\
\text { Recommend }\end{array}$ & 0.808 & 0.045 & 18.528 & $0.002 *$ \\
\hline
\end{tabular}

${ }^{*} \mathrm{p}<0.05 \chi^{2}=902.031(\mathrm{df}=232 \mathrm{p}<0.01) \quad \chi^{2} / \mathrm{df}=3.888$ RMSA: 0.066 GFI: 0.897 CFI: 0.930

Source: Authors' processing

As a result of path analysis, the standardized regression coefficients are given in Table 5 along with their significance. It was determined that cognitive image is the path that significantly influenced affective image $(\beta=0.387, t=7.133)$ and had a positive impact on affective image. In this context, the hypothesis $\mathrm{H} 7$ was accepted. In addition, cognitive image was the path that significantly affected satisfaction $(\beta=0.507, t=9.422)$ and had a positive effect on satisfaction. In this context, the hypothesis H3 was accepted, and it can be put forward that a high cognitive image brings about high satisfaction. However, the hypothesis H6 was rejected because affective image did not have a significant impact on satisfaction $(\beta=0.058, \mathrm{t}=1.312, \mathrm{p}=, 190)$. The Cognitive $(\beta=-0.084, \mathrm{t}=-2.010)$ and affective image $(\beta=0.097, t=2.728)$ paths had a significant effect on intention to recommend. While the cognitive image dimension negatively affected intention to recommend, the affective image dimension affected it positively. In this context, the hypothesis $\mathrm{H} 1$ was rejected, but the hypothesis $\mathrm{H} 5$ was accepted. In addition, the cognitive $(\beta=-0.010, \mathrm{t}=-0.304, \mathrm{p}=0.761)$ and affective $(\beta=0.039, \mathrm{t}=1.434, \mathrm{p}=0.152)$ 


\section{JOURNAL OF TOURISM AND SERVICES}

Issue 21, volume 11, ISSN 1804-5650 (Online)

www.jots.cz

image dimensions did not have a significant impact on intention to revisit (CIU). Accordingly, the hypotheses $\mathrm{H} 2$ and $\mathrm{H} 4$ were rejected. It appears that the satisfaction path significantly affected intention to revisit $(\beta=0.939, \mathrm{t}=23.459)$ and intention to recommend $(\beta=0.808, \mathrm{t}=18.528)$. In this context, the hypotheses $\mathrm{H} 8$ and $\mathrm{H} 9$ were accepted, and it can be suggested that high satisfaction leads to high levels of intention to revisit and intention to recommend. The path analysis for destination image is presented in Figure 2.

Figure 2. Path analysis diagram

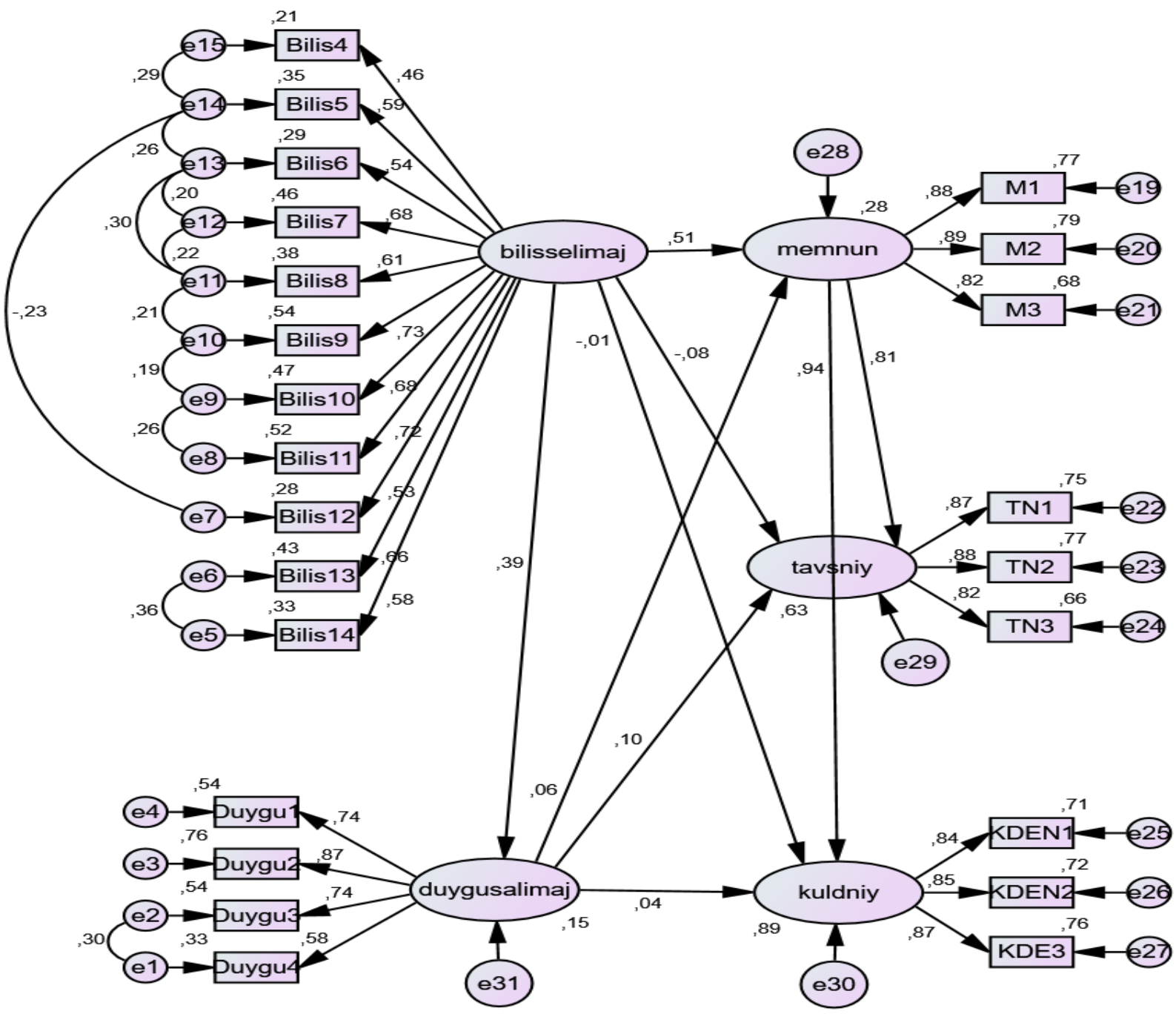

Note: bilisselimaj: cognitive image, duygusalimaj: affective image, memnun: satisfaction, tavsniy: intention to recommend, kuldniy: continued intention to use Source: Authors' processing

Squared multiple correlation values ranged from 0.213 to 0.893 .

\section{Discussion and Conclusion}

In the study, in line with the hypothesis H1, it was found that the cognitive destination image for the Antalya destination did not significantly affect the tourists' intention to revisit the destination. The 


\section{JOURNAL OF TOURISM AND SERVICES}

Issue 21, volume 11, ISSN 1804-5650 (Online)

www.jots.cz

findings related to the hypothesis $\mathrm{H} 1$ obtained in the scope of the study show similarities with the studies by Beckenet al., (2017) (Attractions and infrastructure) and by Styloset al., (2016). In other words, it is concluded that cognitive image does not significantly affect the intention to revisit in these studies. On the other hand, the studies by Nassar et al., (2015, p.43), Hoz-Correa and Munoz-Leiva (2019), Phillips and Jang (2007), and Baloglu (2000) (attractions, quality of experience) have shown that cognitive image affects intention to revisit positively and significantly. A study by Tan and Wu (2016) has revealed that cognitive image of a destination does not play an important role in encouraging first-time visitors to visit the destination in the future, but it positively affects those who have visited the destination previously. Balogluet al. (2015, p.1066-1067) have concluded that cognitive image negatively affects the revisit intentions of first-time visitors, while it negatively influenced repeat visitors' intention to revisit. Another study by Giraldi and Cesareo (2014, p.203) has reported that cognitive destination image has a positive impact on the visit intentions of first-time and repeat visitors. Cognitive destination image is used to describe tourists' ideas or beliefs about a destination or the objective attributes of a destination. The attractions of a destination (historical, cultural and natural), its infrastructure and superstructure facilities, its climate, good relations with the local people in the destination, and personal security issues are associated with cognitive destination image. In this context, it can be claimed that cognitive evaluations are not important for tourists to visit the Antalya destination once again. In this regard, the revisit intention of tourists staying in halal concept hotels are negatively influenced by a variety of factors including the fact that Antalya is a relatively young city compared to its competitors in terms of the most visited destinations, that the city brand image cannot be created, that the city is a very migration-receiving and developing destination, that the local people's behaviour in tourism has begun to be commodified, that the infrastructure facilities are partially insufficient, that the city has an unplanned and distorted urbanization, that the natural environment is not given the necessary sensitivity, that the cultural and historical sites are not adequately arranged, or that the carrying capacity of the city is not considered, and that the perceptions of tourists about personal security could not be adequately removed. As a consequence, within the scope of the hypothesis H1, it can be stated that cognitive destination image does not play an essential role in encouraging tourists who have previously visited Antalya and who prefer to stay in halal concept hotels to revisit the destination or does not affect their intention to revisit.

In the study, it was determined within the scope of the hypothesis H2 that the cognitive destination image for the Antalya destination negatively and significantly affected the tourists' intention to recommend the destination and the hotel. Xu et al., (2018) have concluded that cognitive image does not significantly affect behavioural intentions. On the other hand, Stylidis (2017) has found that cognitive image positively affects intention to recommend, and Balogluet al., (2015) has reported that cognitive image has a positive effect on both the first time visitors' and repeat tourists' intention to recommend. It was determined that as a result of their evaluations of the attributes associated with the cognitive destination image, the tourists staying in the halal concept hotels refrained from recommending the destination and the hotel to their friends and family circles. In the context of the hypothesis $\mathrm{H} 3$, it was concluded that the cognitive destination image related to the Antalya destination positively affected the satisfaction of the tourists. There are many studies in the literature that support the research results (Chen \& Tsai, 2007; Wang \& Hsu, 2010; Chen \& Phou, 2013; Prayag\& Ryan, 2012). The research result within the scope of $\mathrm{H} 3$ was also revealed that while the cognitive image attributes of Antalya positively affected the satisfaction of tourists accommodating in a halal concept hotel, they did not have a positive impact on their intention to recommend the destination and the hotel to family and friends or their intention to revisit the destination and the hotel.

In the study, within the scope of the hypothesis $\mathrm{H} 4$, it was determined that affective destination image did not significantly affect the intention (CIU) of the tourists staying in the halal concept hotels to visit the destination or the hotel. In line with the research findings, Styloset al. (2016) have concluded that affective image does not have a significant effect on intention to revisit. However, the studies by Han $e t$ al., (2019) and by Baloglu (2000) have indicated that affective image significantly and positively affects 


\section{JOURNAL OF TOURISM AND SERVICES}

Issue 21, volume 11, ISSN 1804-5650 (Online)

www.jots.cz

intention to revisit. Similarly, Nassar et al., (2015) point out that affective image significantly and positively affects the intentions of tourists to travel to Islamic destinations, and Phillipsa and Jang (2007) maintain that affective destination image has a significant effect on tourists' intention to visit a destination. In the studies conducted by Tan and Wu (2016), by Balogluet al., (2015) and by Giraldi and Cesareo (2014) to determine how the affective images of first-time and repeat visitors affect their intention to visit a destination, it is concluded that affective destination image has a positive impact on the revisit intentions of first-time and repeat visitors.

Affective destination image is described as the feelings and emotions that tourists create in their minds in connection with a destination as well as the abstract reflections in their minds which they obtain from the travel experience at the destination or the emotional responses of tourists towards the destination. Affective dimension expresses positive, negative or neutral feelings for a destination, and these affective evaluations of tourists are important for Turkish tourism, which has a fragile tourism structure. Affective evaluations can play a vital role in eliminating the negative attributes of a destination by preventing tourists from making rational decisions. The instability in Turkish tourism can lead to economic losses in tourism around the country, a decrease in employment or an increase in labor turnover in the sector, loss of the standards in the quality of service offered by hotel establishments, and frequent handover of hotel establishments and closure of hotels in certain periods or a limitation in room supply. Affective evaluations play a key role in reducing tourism fluctuations. The affective dimension is of great importance in transforming the plans of potential first-time visitors and repeat visitors into behaviour or action. In order to create affective image evaluations, which significantly affect intention to revisit, in tourists, first of all, cognitive image evaluations must be well established in tourists. Indeed, this view is supported by a variety of studies that have identified the impact of cognitive image evaluations on affective image evaluations (Stylidiset al., 2017; Papadimitriou et al., 2015; Li et al.,2010; Wang \& Hsu, 2010; Lin et al., 2007; Baloglu, 2000). It also coincides with the research findings which reveal the effect of cognitive destination image on affective destination image (the hypothesis H7). In other words, it can be claimed that an insignificant cognitive image evaluation will result in insignificant affective image evaluation. Another reason why affective destination image does not significantly affect tourists' intention to revisit the destination or the hospitality establishment that offers the halal concept is that they do not have any emotional bonds which can make them feel close to or identify themselves with the destination and the hospitality establishment since the all-inclusive system pushes the tourists not to leave the resort. In addition, as another reason it can be put forward that the halal concept is not applied in the hospitality establishment in real terms, or in other words, there are no hotels operating in Antalya with halal certification received from Turkish Standards Institution (TSI) or from internationally accredited certification bodies to show that these conditions are fulfilled. As a matter of fact, hotels that define themselves as halal operate in this concept in Antalya (Isedak, 2017). What is more, in the context of the hypothesis $\mathrm{H} 6$ in the study, it was concluded that affective destination image does not significantly affect the satisfaction of tourists staying in halal concept hotels. The results of the study conducted by Kaplanidou and Vogt (2007) coincide with the findings in H6. It can be argued that the fact that the affective images of the tourists staying in halal concept hotels do not have a significant effect on their satisfaction may also be a factor that causes the hypothesis $\mathrm{H} 4$ not to be significant. This is because an insignificant relationship between affective image and satisfaction can be suggested to affect the relationship between affective image and intention to revisit, too.

In the study, it was found within the scope of the hypothesis $\mathrm{H} 5$ that the affective destination image positively and significantly affected the intention of tourists staying in the halal concept to recommend the destination or the hotel. Similar to the research results, Han et al., (2019), Beckenet al., (2017), Stylidis (2017), and Xu et al., (2018) have also found that affective image has a positive and significant impact on tourists' intentions to recommend the destination. In addition, Balogluet al., (2015) have concluded that affective destination image positively influences the recommendations of both firsttime and repeat tourists. It can be put forward that while affective destination image does not significantly 


\section{JOURNAL OF TOURISM AND SERVICES}

Issue 21, volume 11, ISSN 1804-5650 (Online)

www.jots.cz

affect the satisfaction of the tourists staying in the halal concept and their intention to revisit (CIU), it is an important finding that the tourists' intention to recommend the Antalya destination and the hotel establishment which applies the halal concept to their family and friends is significant and positive. Although the affective image evaluations (feelings and emotional reactions towards the destination) of the tourists are not a significant path for the variables of satisfaction and intention to revisit, it can be suggested that tourists tend to recommend the destination and the hotel establishment that applies the halal concept to their family and friends considering the fact that the path for intention to recommend the destination and the hotel that applies the halal concept is significant and positive.

According to the research findings, the satisfaction of tourists with the service provided by the hotel enterprises (the hypotheses $\mathrm{H} 8$ and $\mathrm{H} 9$ ) brings about a high level of recommendation and revisiting. In other words, it can be argued that satisfaction will lead to a high level of intention to recommend and will have a higher level of intention to revisit the hotel establishment, which applies the halal concept. The research findings are supported by various studies that have determined that satisfaction with respect to the destination image affects behavioural intentions positively and significantly ( $\mathrm{Xu}$ et al., 2019; Loiet al., 2017; Stylidiset al., 2017; Assaker\&Hallak 201; Tavitiyaman\& Qu 2013; Prayag\& Ryan 2012; Wang \& Hsu 2010). In addition, the studies by Kozak and Rimmington (2000), Rittichainuwatet al., (2003), Hui et al., (2007) and Lee et al., (2007) also confirm that overall satisfaction is essential to turn intention to visit and intention to recommend into action. On the other hand, Foroudiet al., (2018) have found that satisfaction significantly and positively affects intention to recommend and intention to revisit, but that intention to revisit does not affect intention to recommend. Kim (2017) reports that overall satisfaction affects intention to revisit and word-of-mouth (WOM) positively, but that it has a higher impact on intention to revisit compared to word-of-mouth (WOM). Souidenet al., (2017) have concluded that destination image has an indirect effect on behavioural intentions. It can be put forward that tourists who are satisfied with the Antalya destination and the hotel establishment in this destination will revisit the Antalya destination and the hotel establishment with halal concept and recommend them to their family and friends. It can be stated that tourists, who are satisfied with the destination and the hotel establishment, are more likely to revisit the destination compared to the possibility of recommendation.

The fact that intention to recommend and intention to revisit is significant and positive has many advantages in terms of the destination and the hospitality establishment. The managers of the hotels applying the halal concept should make a lot of effort to ensure that the tourists are satisfied, so that those who are satisfied will visit the hotel once more and recommend it to their family and friend circles, which will in turn reduce the advertising and promotion expenses of the establishment and cause wordof-mouth (WOM). It can be suggested that the tourists who come to stay in a halal concept hotel with the advice of a friend, will have confidence about this concept and the hospitality establishment in the light of the information obtained from their own friend circles that they trust, and their doubts will decrease about this concept, which is a recent practice. It can be stated that if satisfied tourists recommend a destination or a hotel to their friends, potential tourists can easily have an awareness and positive attributes about the Antalya destination in their minds, and the hotel establishment, and the destination can get ahead in the decision-making process of the tourists in this global environment, where there is intense competition between the destinations.

Considering that the classic advertising and promotion tools become dysfunctional, it can be claimed that Antalya destination and hotel establishments will effortlessly gain a place in the minds of potential tourists by having a strong promotion and advertisement through positive word-of-mouth, or that it will be easier for positive emotions about the destination and the hospitality establishments to put down roots in the minds of potential tourists. Also, the fact that the intention to revisit is significant may cause tourists staying in hotels with this concept to feel loyal towards the hotel establishments and the destination. Considering that tourism is easily affected by many external factors (war, terrorist attacks, epidemic etc.), the formation of tourist loyalty towards the hotel establishments and the destination, can be important for tourists to visit the destination and the hotel more willingly compared to other tourists 


\section{JOURNAL OF TOURISM AND SERVICES}

Issue 21, volume 11, ISSN 1804-5650 (Online)

www.jots.cz

and in reducing vulnerability in tourism in crisis years like 2016 (Aktob, 2019). Furthermore, prevention of cyclical fluctuations in tourism has importance in settling external deficit in economy with the currency coming from tourism in Turkey, which is in the category of developing countries and in stabilizing the generated currency revenue. The study conducted by Fuch, Reichel (2011) to reveal the difference between first time visitors and repeat visitors in terms of destination risk perceptions indicates that firsttime visitors are characterized by socio-psychological risk, food safety and weather risk, while repeat visitors are associated with the destination risk factors related to service quality risk, natural disasters, car accidents and financial risk. As a result of the present study, the fact that repeat visitors to a destination and hotel establishment, that is loyal customers, have different risk assessments compared to first time visitors, or that they have less risk sensitivity than first time visitors, and that they are associated with risk groups that are very difficult to control (natural disasters) instead of risks arising from uncertainty.

When the relationships between cognitive and affective destination images, intention to recommend and intention to revisit (CIU) and satisfaction are evaluated, it is determined that unlike affective image, cognitive image has a positive and significant impact on satisfaction. It is observed that both cognitive and affective destination images affect intention to recommend positively and significantly. On the other hand, it can be stated that neither cognitive destination image nor affective destination image significantly and directly affects the destination or the hotel establishment that apply the halal concept. It can be suggested that if destination authorities and managers of the hotels with the halal concept focus on cognitive image elements in the context of satisfaction, the probability of success will be higher in affecting tourist satisfaction compared to affective image elements. On the other hand, while the cognitive destination image evaluations of the tourists negatively and significantly influence their intention to recommend, their affective image evaluations have a positive and significant effect on it, which means that if the focus is put on affective image elements success can be achieved in the context of intention to recommend even though cognitive image elements are low $(\beta=-0.84)$. However, the fact that cognitive and affective destination image elements do not have a direct significant impact on intention to revisit the destination and the hotel establishment (CIU) requires that the managers of the hotels with halal concept and the authorities of the destination and focus on the intention to revisit (CIU) through another mediator variable.

Within the context of the hypothesis $\mathrm{H} 7$ in the study, it was determined that cognitive destination image positively and significantly affects affective destination image of the tourists staying in halal concept hotels. In other words, a high cognitive destination image can be suggested to cause a high destination image. Many studies supporting the research finding that cognitive evaluations have a positive impact on affective evaluations (Stylidiset al., 2017; Papadimitriou et al., 2015; Li et al.,2010; Wang \& Hsu, 2010; Lin et al., 2007; Baloglu, 2000). Cognitive destination image is based on the belief and knowledge of the people about a destination $\mathrm{n}$ and the destination attributes that help create an internal mental image of the place as well as on tourist destination sources such as landscape, climate, accommodation facilities, restaurants, and historical and cultural attractions. Affective destination image refers to emotions and emotional responses to a destination (Stylidiset al., 2017). In the literature, the view that people's affective evaluations depend on their knowledge of a place (destination) is widely dominated. In other words, people develop emotions about a destination after cognitive evaluation. As a result of the research, it can be stated that after cognitively evaluating the Antalya destination in terms of tourists staying in a halal concept hotel, this turns into emotions towards the destination. It is supported by the research findings that the destination of Antalya and its features (climate, landscape, infrastructure and superstructure features, and historical and cultural attractions) turn into affective evaluations in tourists staying in a halal concept hotel.

\section{Implications and Limitations}




\section{JOURNAL OF TOURISM AND SERVICES}

Issue 21, volume 11, ISSN 1804-5650 (Online)

www.jots.cz

When the results of the study are evaluated in general, it can be suggested that the study has some theoretical and managerial contributions. As for theoretical contributions, first of all, considering that the literature on halal tourism, which is a recent concept, is still in its infancy, the present study will make an important contribution to the enrichment and development of the literature. Second, the study makes valuable contributions to revealing the destination image evaluations of tourists staying in hotels with the concept of halal tourism with respect to Antalya. The last and most important theoretical contribution of the study is that it enables the development of the literature and the evaluation of the subject in terms of different variables by determining the relationships between the proposed model and the variables and their effects on each other. When it comes to managerial contributions, determining the destination image evaluations of tourists and identifying the relationships between destination image and variables of tourist satisfaction and behavioural intentions reveal important practical implications in the context of developing policies and strategies for the managers of the hotels which apply the halal tourism concept and for local authorities in the destination where these hotels are located.

The study has some limitations that can be overcome in future research. The main research limitation is that it is a research conducted on domestic and foreign tourists staying in 6 hotel establishments that apply the concept of halal tourism in the Antalya destination. In future research, sample size can be expanded in two ways: Firstly, tourists who stay in hotels with halal concept in different destinations can be included in the study and secondly, the study can be carried out more heterogeneously on all tourists staying in hotels with this concept without selecting a destination. Another limitation of the research is that it is a quantitative research using questionnaires as data collection instruments. The main purpose of quantitative studies is to evaluate trends, attitudes and opinions across the universe through studies on a sample selected from the universe. In other words, inferences can be made with respect to the universe with the data obtained from the sample (Creswell and Creswell, 2017). Especially in recent years, the reluctance and inattention of businesses and participants to fill out questionnaires makes it difficult to obtain healthy results or even prevents it. For this reason, instead of presenting the preconceived opinions of the researchers on the subject, the feelings and behaviour of the tourists in hotel establishments that operate for the region in a specific context can be examined through qualitative methodology. With such a study, more subjective and exploratory results regarding the variables can be achieved. Thematic analysis can be performed on the rich data obtained from hotel establishments and the dimensions of the relevant variables can be examined in depth. Other studies like the present one can be conducted in different regions and countries to compare the perspectives of tourists provided that the sample size is sufficient. Furthermore, although the relationships between the cognitive and affective destination image dimensions and satisfaction and behavioural intentions are examined in detail in the present study, it can be recommended for future studies to investigate how cognitive image affects the three outputs via affective image and whether affective image has a mediating effect on the relationship.

\section{Acknowledgement}

This article is derived from the doctoral dissertation completed by YenalYağmur in December 2019 under the direction of Akın Aksu in the Tourism Management program of Akdeniz University Institute of Social Sciences in Antalya-Turkey.

\section{References}

1. Abral, W. (2017). The formulation of student social interaction model at halal tourism area on Lombok Island, Sumatra. Journal of Disaster, Geography and Geography Education, 1(2), 234-241.

2. Ahmed, M. J. \&Akbaba, A. (2018). The potential of halal tourism in Ethiopia: opportunities, challenges and prospects. International Journal of Contemporary Tourism Research, 2(1), 13-22. doi:10.30625/ijctr.397499. 


\section{JOURNAL OF TOURISM AND SERVICES}

Issue 21, volume 11, ISSN 1804-5650 (Online)

www.jots.cz

3. Aktob (Mediterranean Touristic Hoteliers Association). (2019) Turizmdeistikrarsürerken, dünyadaki yeni yerimizedoğru. Resort TurizmPerspektif, 194, 1-31.

4. Alaeddinoglu, F. \& Can, A. S. (2010). Destination image from the perspective of travel intermediaries. Anatolia, 21(2), 339-350. doi:10.1080/13032917.2010.9687107.

5. Alam, S. S. \&Sayuti, N. M. (2011). Applying the theory of planned behavior (TPB) in halal food purchasing. International Journal of Commerce and Management, 21(1), 8-20. doi:10.1108/10569211111111676.

6. Altunışık, R., Coşkun, R., Bayraktaroğlu S. \&Yıldırım, E. (2012). Sosyalbilimlerdearaștırmayöntemleri SPSS uygulamalı 7. Bask1, SakaryaYayınları, İstanbul.

7. Assaker, G. \&Hallak, R. (2013). Moderating effects of tourists' novelty-seeking tendencies on destination image, visitor satisfaction, and short and long-term revisit intentions. Journal of Travel Research, 52(5), 600-613.doi:10.3727/108354215X14411980111415.

8. Atadil, H. A., Sirakaya-Turk, E. \&Altintas, V. (2017). An analysis of destination image for emerging markets of Turkey. Journal of Vacation Marketing, 23(1), 37-54. doi:10.1177/1356766715616858.

9. Baloglu, S. \&Brinberg, D. (1997). Affective images of tourism destinations. Journal of Travel Research, 35(4), 11-15. doi:10.1177/004728759703500402.

10.Baloglu, S. \&Mangaloglu, M. (2001). Tourism destination images of Turkey, Egypt, Greece, and Italy as perceived by US-based tour operators and travel agents. Tourism Management, 22(1), 1-9. doi:10.1016/S0261-5177(00)00030-3.

11.Baloglu, S. \& McCleary, K. W. (1999). A model of destination image formation. Annals of Tourism Research, 26(4), 868-897. doi:10.1016/S0160-7383(99)00030-4.

12.Baloglu, S. (2000). A path analytic model of visitation intention involving information sources, socio-psychological motivations, and destination image. Journal of Travel \&Tourism Marketing, 8(3), 81-90. doi:10.1300/J073v08n03_05.

13.Baloglu, S.\& Love, C. (2005). Association meeting planners' perceptions and intentions for five major US convention cities: the structured and unstructured images. Tourism Management, 26(5), 743-752. doi:10.1016/j.tourman.2004.04.001.

14.Baloglu, S., Henthorne, T. L. \&Sahin, S. (2015). Destination image and brand personality of Jamaica: a model of tourist behavior. Journal of Travel \&Tourism Marketing, 31(8), 1057-1070. doi:10.1080/10548408.2014.892468.

15.Battour, M. \& Ismail, M. N. (2016). Halal tourism: concepts, practises, challenges and future. Tourism Management Perspectives, 19, 150-154. doi:10.1016/j.tmp.2015.12.008.

16.Becken, S., Jin, X., Zhang, C. \& Gao, J. (2017.) Urban air pollution in China: destination image and risk perceptions. Journal of Sustainable Tourism, 25(1), 130-147. doi:10.1080/09669582.2016.1177067.

17.Beerli, A. \& Martin, J. D. (2004). Factors influencing destination image. Annals of Tourism Research, 31(3), 657-681. doi:0.1016/j.annals.2004.01.010.

18.Bigne, J. E., Sanchez, M. I. \& Sanchez, J. (2001). Tourism image, evaluation variables and after purchase behaviour: inter-relationship. Tourism Management, 22(6), 607-616. doi:10.1016/S02615177(01)00035-8.

19.Chanin, O., Sriprasert, P., Rahman, H. A. \& Don, M. S. (2015). Guidelines on halal tourism management in the Andaman Sea Coast of Thailand. Journal of Economics, Business and Management, 3(8): 791-794. doi:10.7763/JOEBM.2015.V3.287.

20.Chen, C. F. \& Phou, S. (2013). A closer look at destination: image, personality, relationship and loyalty. Tourism Management, 36, 269-278. doi:10.1016/j.tourman.2012.11.015.

21.Chen, C. F. \& Tsai, D. (2007). How destination image and evaluative factors affect behavioral intentions? Tourism Management, 28(4), 1115-1122. doi:10.1016/j.tourman.2006.07.007. 


\section{JOURNAL OF TOURISM AND SERVICES}

Issue 21, volume 11, ISSN 1804-5650 (Online)

www.jots.cz

22.Creswell, J. W. \& Creswell, J. D. (2017). Research design: qualitative, quantitative, and mixed methods approaches. London: Sage Publications.

23.Crompton, J. L. (1979). Motivations for pleasure vacation. Annals of Tourism Research, 6(4), 408424.

24.Dube, F. N., Hongxia, Z., Haijuan, Y. \& Lijun, H. (2016). Halal certification system as a resource for firm internationalisation: comparison of China and Malaysia. IJAPS, 12 (1), 125-141.

25.Echtner, C. M. \& Ritchie, J. R. (2003). The meaning and measurement of destination image [Reprint of original article published in v. 2, no. 2, 1991: 2-12.]. Journal of Tourism Studies, 14(1), 37.

26.Echtner, C. M., \& Ritchie, J. B. (1991). The meaning and measurement of destination image. Journal of Tourism Studies, 2(2), 2-12.

27.Echtner, C. M., \& Ritchie, J. B. (1993). The measurement of destination image: an empirical assessment. Journal of Travel Research, 31(4), 3-13. doi:10.1177/004728759303100402.

28.Elaziz, M. F. \& Kurt, A. (2017). Religiosity, consumerism and halal tourism: a study of seaside tourism organizations in Turkey. Turizam: MeđunarodniZnanstveno - StručniČasopis, 65(1), $115-128$.

29.Euromonitor International (2019). Top 100 City Destinations Report. https://go.euromonitor.com/white-paper-travel-2019-100-cities, Retrieved August 17, 2020.

30.Fakeye, P. \& J. Crompton (1991). Image differences between prospective, first-time, and repeat visitors to the Lower Rio Grande Valley. Journal of Travel Research, 30(2),10-16. doi:10.1177/004728759103000202.

31.Font, X. (1997). Managing the tourist destination's image. Journal of Vacation Marketing, 3(2), 123131.

32.Foroudi, P., Akarsu, T. N., Ageeva, E., Foroudi, M. M., Dennis, C. \& Melewar, T. C. (2018). Promising the dream: changing destination image of London through the effect of website place. Journal of Business Research, 83, 97-110. doi:10.1016/j.jbusres.2017.10.003.

33.Fuchs, G. \& Reichel, A. (2011). An exploratory inquiry into destination risk perceptions and risk reduction strategies of first time vs. repeat visitors to a highly volatile destination. Tourism Management, 32(2), 266-276. doi:10.1016/j.tourman.2010.01.012.

34.Gabdrakhmanov, N. K., Biktimirov, N. M., Rozhko, M. V. \&Mardanshina, R. M. (2016). Features of Islamic tourism. Academy of Marketing Studies Journal, 20, 45-50.

35.Gallarza, M. G., Saura, I. G. \& Garcia, H. C. (2002). Destination image: towards a conceptual framework. Annals of Tourism Research, 29(1), 56-78. doi:10.1016/S0160-7383(01)00031-7.

36.Gartner, W. (1989). Tourism image: attribute measurement of state tourism products using multidimensional scaling techniques. Journal of Travel Research, 28(2), 16-20.

37.Gartner, W. C. (1994) Image formation process. Journal of Travel \& Tourism Marketing, 2(2-3), 191216. doi:10.1300/J073v02n02_12.

38.Garver, M. S. \& Mentzer, J. T. (1999). Logistics research methods: employing structural equation modeling to test for construct validity. Journal of Business Logistics, 20(1), 33-57.

39.Giraldi, A. \&Cesareo, L. (2014). Destination image differences between first-time and return visitors: an exploratory study on the city of Rome. Tourism and Hospitality Research, 14(4), 197-205. doi: $10.1177 / 1467358414543971$.

40.Hair, J. F., Black, W. C., Babin, B. J. and Anderson, R. E. (2014). Multivariate data analysis. Pearson New International Edition, Seventh Edition.

41.Hair, J. F., Black, W. C., Babin, B. J., Anderson, R. E. \& Tatham, R. L. (2009). Multivariate data analysis. Pearson New International Edition.

42.Han, H., Al-Ansi, A., Olya, H. G. \& Kim, W. (2019). Exploring halal-friendly destination attributes in South Korea: perceptions and behaviors of Muslim travelers toward a non-Muslim destination. Tourism Management, 71, 151-164. doi:10.1016/j.tourman.2018.10.010. 


\section{JOURNAL OF TOURISM AND SERVICES}

Issue 21, volume 11, ISSN 1804-5650 (Online)

www.jots.cz

43.Haque, A. \&Momen, A. (2017). A model of Islamic tourism towards religious motivation and tourist satisfaction in Malaysia. Social Interactions and Networking in CyberSociety. Editors: Ford LumbanGaol, FonnyDameatyHutagalung. Springer. 153-167.

44.Henderson, J. C. (2016). Muslim travellers, tourism industry responses and the case of Japan. Tourism Recreation Research, 41(3), 339-347. doi: 10.1080/02508281.2016.1215090.

45.Ho, R. (2014). Handbook of univariate and multivariate data analysis with Ibm-Spss. Newyork: Chapman and Hall/CRC.

46.Hosany, S., Ekinci, Y. \&Uysal, M. (2006). Destination image and destination personality: an application of branding theories to tourism places. Journal of Business Research, 59(5), 638-642. doi:10.1016/j.jbusres.2006.01.001.

47.Hosany, S., Ekinci, Y. \&Uysal, M. (2007). Destination image and destination personality. International Journal of Culture, Tourism and Hospitality Research, 1(1), 62-81. doi:10.1108/17506180710729619.

48.Hoz-Correa, A. \& Munoz-Leiva, F. (2018). The role of information sources and image on the intention to visit a medical tourism destination: a cross-cultural analysis. Journal of Travel \&Tourism Marketing, 36(2), 204-2019. doi: 10.1080/10548408.2018.1507865.

49.Hui, T. K., Wan, D. T. W. \& Ho, A. (2007). Tourists' satisfaction, recommendation and revisiting Singapore. Tourism Management, 28, 965-975. doi:10.1016/j.tourman.2006.08.008.

50.Hunt, J. (1971). Image-A factor in tourism. Doctoral Dissertation, Colorado State University, Fort Collins, Colorado.

51.Hunt, J. (1975) Image as a factor in tourism development. Journal of Travel Research, 13(3), 1-17.

52.Iordanova-Krasteva, E. (2013). Understanding destination image: the case of Linz. Doctoral Dissertation. Department of Design, Media and Management, Brunel University, UK.

53.Isedak (COMCEC, The Standing Committee for Economic and Commercial Cooperation of the Organization of the Islamic Cooperation). (2017). MüslümanDostuTurizm: IIIT ÜyesiÜlkelerdeKonaklamaTesislerineilliskinDüzenlemeler. İsedakKomisyonOfisi.

54.Jafari, J. \& Scott, N. (2014). Muslim world and its tourisms. Annals of Tourism Research, 44, 1-19. doi:10.1016/j.annals.2013.08.011.

55.Jeong, C. \& Holland, S. (2012). Destination image saturation. Journal of Travel \&Tourism Marketing, 29(6), 501-519. doi: 10.1080/10548408.2012.701162.

56.Kalayc1, Ş. (2018). Spssuygulamahçokdeğişkenliistatistikteknikleri. 9. Bask1, DinamikAkademi, Ankara.

57.Kaplan, M. F. (1991). The joint effects of cognition and affect on social judgment. In J. P. Forgas, (Ed.), Emotion and social judgments (pp. 73-82). New York: Pergamon Press.

58.Kaplanidou, K. \& Vogt, C. (2007). The interrelationship between sport event and destination image and sport tourists'behaviours. Journal of Sport \& Tourism, 12(3-4), 183-206. doi:10.1080/14775080701736932.

59.Karagöz, Y. (2017). Bilimselaraştırmayöntemleriveyaynetiği: Spssve Amos uygulamalnitel-nicel-karma. Nobel AkademikYayıncilik.

60.Kastenholz, E. (2010). Cultural proximity as a determinant of destination image. Journal of Vacation Marketing, 16(4), 313-322. doi:10.1177/1356766710380883.

61.Kim, J. H. (2017). The impact of memorable tourism experiences on loyalty behaviors: the mediating effects of destination image and satisfaction. Journal of Travel Research, 1-15. doi:10.1177/0047287517721369.

62.Kock, F., Josiassen, A. \& Assaf, A. G. (2016). Advancing destination image: the destination content model. Annals of Tourism Research, 61, 28-44. doi:10.1016/j.annals.2016.07.003.

63.Kotler, P. (1994). Marketing management: analysis, planning implementation and control. NJ: Prentice Hall International.

64.Kozak, M. \&Rimmington, M. (2000). Tourist satisfaction with Mallorca, Spain, as an off-season holiday destination. Journal of Travel Research, 38(3), 260-269. 


\section{JOURNAL OF TOURISM AND SERVICES}

Issue 21, volume 11, ISSN 1804-5650 (Online)

www.jots.cz

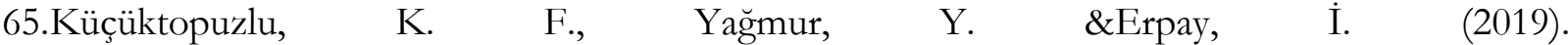
İlahiyatfakültesiöğretimüyelerininhelalturizmeyönelikbakışaçıları. Journal of Turkish Tourism Research, 3(4), 1349-1370. doi:10.26677/TR1010.2019.246.

66.Latif, A. I., Mohamed, Z., Sharifuddin, J., Abdullah, A. M. \& Ismail, M. M. (2014). A comparative analysis of global halal certification requirements. Journal of Food Products Marketing, 20(1), 85-101. doi:10.1080/10454446.2014.921869.

67.Lawson, F. \& M. Baud-Bovy (1977). Tourism and recreational development. London: Architectural Press.

68.Lee, C. K., Lee, Y. K. \& Lee, B. (2005). Korea's destination image formed by the 2002 World Cup. Annals of Tourism Research, 32(4), 839-858. doi:10.1016/j.annals.2004.11.006.

69.Lee, C. K., Yoon, Y. S. \& Lee, S. K. (2007). Investigating the relationships among perceived value, satisfaction, and recommendations: the case of the Korean DMZ. Tourism Management, 28(1), 204214. doi:10.1016/j.tourman.2005.12.017.

70.Li, M., Cai, L. A., Lehto, X. Y. \& Huang, J. (2010). A missing link in understanding revisit intention - the role of motivation and image. Journal of Travel \&Tourism Marketing, 27(4), 335-348. doi:10.1080/10548408.2010.481559.

71.Li, X. R. \& Vogelsong, H. (2006). Comparing methods of measuring image change: a case study of a small-scale community festival. Tourism Analysis, 10(4), 349-360. doi:10.3727/ 108354206776162769.

72.Lin, C. H., Morais, D. B., Kerstetter, D. L. \& Hou, J. S. (2007). Examining the role of cognitive and affective image in predicting choice across natural, developed, and theme-park destinations. Journal of Travel Research, 46(2), 183-194. doi:10.1177/0047287507304049.

73.Loi, L. T. I., So, A. S. I., Lo, I. S. \& Fong, L. H. N. (2017). Does the quality of tourists shuttles influence revisit intention through destination image and satisfaction? The case of Macao. Journal of Hospitality and Tourism Management, 32, 115-123.doi:10.1016/j.jhtm.2017.06.002.

74.Mano, A. \& Costa, R. A. (2015). A conceptual model of the antecedents and consequences of tourist destination image. Procedia Economics and Finance, 23, 15-22. doi:10.1016/S22125671(15)00466-9.

75.Milman, A., \&Pizam, A. (1995). The role of awareness and familiarity with a destination: the central Florida case. Journal of Travel Research, 33(3), 21-27. doi:10.1177/ 004728759503300304.

76.Musa, G., Mohezar Ali, S. \&Moghavvemi, S. (2016). Understanding Islamic (halal) tourism through Leiper's Tourism System, 1-25.

77.Nakip, M. (2003). Pąarlamaarașturmalar: tekniklerveuygulamalar. SeçkinKitabevi, Ankara.

78.Nassar, M. A., Mostafa, M. M. \& Reisinger, Y. (2015). Factors influencing travel to Islamic destinations: an empirical analysis of Kuwaiti Nationals. International Journal of Culture, Tourism and Hospitality Research, 9(1), 36-53. doi:10.1108/IJCTHR-10-2014-0088.

79.Olya, H. G., \& Al-ansi, A. (2018). Risk assessment of halal products and services: Implication for tourism industry. Tourism Management, 65, 279-291. doi:10.1016/j.tourman.2017.10.015.

80.Pamukçu, H. \&Arpac1, Ö. (2016). A new trend in the Turkish tourism industry: halal tourism. Global issues and trends in tourism. St. KlimentOhridski University Press, Sofia, Bulgaria.

81.Papadimitriou, D., Apostolopoulou, A. \&Kaplanidou, K. (2015). Destination personality, affective image, and behavioral intentions in domestic urban tourism. Journal of Travel Research, 54(3), 302-315. doi:10.1177/0047287513516389.

82.Pew Research Center, (2017). The changing global religious landscape: babies born to Muslims will begin to outnumber Christian births by 2035; People with no Religion Face a Birth Dearth, Washington, http://www.pewresearch.org.

83.Phillips, W. \& Jang, S. (2007). Destination image and visit intention: examining the moderating role of motivation. Tourism Analysis, 12(4), 319-326. doi:10.3727/108354207782212387. 


\section{JOURNAL OF TOURISM AND SERVICES}

Issue 21, volume 11, ISSN 1804-5650 (Online)

www.jots.cz

84.Prayag, G. \& Ryan, C. (2012). Antecedents of tourists' loyalty to Mauritius: the role and influence of destination image, place attachment, personal involvement, and satisfaction. Journal of Travel Research, 51(3), 342-356. doi:10.1177/0047287511410321.

85.Prayag, G. (2009). Tourists' evaluations of destination image, satisfaction, and future behavioral intentions-the case of Mauritus. Journal of Travel \&ourism Marketing, 26(8), 836- 853. doi:10.1080/10548400903358729.

86.Prayag, G. (2020) Halal tourism: looking into the future through the past. Tourism Recreation Research, 1-3. doi:10.1080/02508281.2020.1762044.

87.Puangniyom, P., Swangcheng, N. \&Mahamud, T. (2017). Halal tourism strategy to promote sustainable cultural tourism in Thailand. 2017-Cebu (Philippines) International Conference on Studies in Arts, Social Sciences and Humanities (Sassh-17), 194-198.

88.Razzaq, S., Hall, C. M. \&Prayag, G. (2016). The capacity of New Zealand to accommodate the halal tourism market-or not. Tourism Management Perspectives, 18, 92-97. doi:0.1016/j.tmp.2016.01.008.

89.Rittichainuwat, B. N., Qu, H. \&Mongknonvanit, C. (2002). A Study of the impact of travel satisfaction on the likelihood of travelers to revisit Thailand. Journal of Travel \&Tourism Marketing, 12(2-3): 19-43. doi:10.1300/J073v12n02_03.

90.Rodrigues, A. I., Correia, A. \& Kozak, M. (2011). A multidisciplinary approach on destination image construct. Tourismos: an international multidisciplinary. Journal of Tourism, 6(3), 93-110.

91.Ryan, C. (2016). Halal tourism-Editorial. Tourism Management Perspectives, 19, 121-123. doi:10.1016/j.tmp.2015.12.014.

92.Sahida, W., Rahman, S., Wahidin, K.A. \& Man, Y.B.C. (2011). Developing the framework for halal friendly tourism in Malaysia. International Business Management, 5(6), 295-302.

93.Sahin, S. \&Baloglu, S. (2011). Brand personality and destination image of Istanbul, Anatolia. An International Journal of Tourism and Hospitality Research, 22(01), 69-88. doi:10.1080/13032917.2011.556222.

94.Samori, Z., Salleh, N. Z. M., \& Khalid, M. M. (2016). Current trends on halal tourism: cases on selected Asian countries. Tourism Management Perspectives, 19, 131 136.doi:10.1016/j.tmp.2015.12.011.

95.Schreiber, J. B., Nora A., Stage F. K., Barlow E. A. \& King J. (2006). Reporting structural equation modeling and confirmatory factor analysis results: a review. The Journal of Educational Research, 99(6), 323-337. doi:10.3200/ JOER.99.6.323-338.

96.Sharma, S. (1996). Applied multivariate techniques. John Wiley and Sons Inc., Newyork.

97.Smith, S. L. (1994). The tourism product. Annals of Tourism Research, 21(3), 582-595.

98.Sonmez, S., \&Sirakaya, E. (2002). A distorted destination image? The case of Turkey. Journal of Travel Research, 41(2), 185-196. doi:10.1177/004728702237418.

99.Souiden, N., Ladhari, R. \&Chiadmi, N. E. (2017). Destination personality and destination image. Journal of Hospitality and Tourism Management, 32, 54-70. doi:10.1016/j.jhtm.2017.04.003.

100. Stepchenkova, S. \& Mills, J. E. (2010). Destination image: a meta-analysis of 2000-2007 research. Journal of Hospitality Marketing \& Management, 19(6), 575-609. doi:10.1080/19368623.2010.493071.

101. Stern, E. \&Krakover, S. (1993). The formation of a composite urban image. Geographical Analysis, 25(2), 130-146. doi:10.1111/j.1538-4632.1993.tb00285.x.

102. Stylidis, D., Shani, A. \&Belhassen, Y. (2017). Testing an integrated destination image model across residents and tourists. Tourism Management, 58, 184-195. doi:10.1016/j.tourman.2016.10.014. doi:10.1016/j.tourman.2016.10.014.

103. Stylos, N., Vassiliadis, C. A., Bellou, V. \&Andronikidis, A. (2016.) Destination images, holistic images and personal normative beliefs: predictors of intention to revisit a destination. Tourism Management, 53, 40-60. doi:10.1016/j.tourman.2015.09.006. 


\section{JOURNAL OF TOURISM AND SERVICES}

Issue 21, volume 11, ISSN 1804-5650 (Online)

www.jots.cz

104. Talib, M. S. A., Hamid, A. B. A. \& Chin, A. T. (2016). Motivations and limitations in implementing halal food certification: a pareto analysis. British Food Journal, 117(11), 2664-270. doi:10.1108/BFJ-02-2015-0055.

105. Tan, W. K. \& Wu, C. E. (2016). An investigation of the relationships among destination familiarity, destination image and future visit intention. Journal of Destination Marketing \& Management, 5(3), 214-226. doi:10.1016/j.jdmm.2015.12.008.

106. Tasci, A. D. \& Gartner, W. C. (2007). Destination image and its functional relationships. Journal of Travel Research 45(4), 413-425.

107. Tasci, A. D., Gartner, W. C. \& Tamer Cavusgil, S. (2007). Conceptualization and operationalization of destination image. Journal of Hospitality \& Tourism Research, 31(2), 194-223. doi:10.1177/1096348006297290.

108. Tavitiyaman, P. \& Qu, H. (2013). Destination image and behavior intention of travelers to Thailand: the moderating effect of perceived risk. Journal of Travel \&Tourism Marketing, 30(3), 169-185. doi:10.1080/10548408.2013.774911.

109. TSI (Turkish Standards Institution) Ts-13683. (2016). Helalyönetimsistemi- Oteller.

110. Tuna, F. (2016). The role and potential of halal tourism in Turkey. Geo Journal Library 121, (Editor: Istvan Egresi), Alternative Tourism in Turkey: Role, Potential Development and Sustainability, 259-267.

111. Wang, C. Y. \& Hsu, M. K. (2010). The relationships of destination image, satisfaction, and behavioral intentions: an integrated model. Journal of Travel \&ourism Marketing, 27(8), 829843. doi:10.1080/10548408.2010.527249.

112. Wang, Y., Li, X. \& Lai, K. (2018). A meeting of the minds: exploring the core-periphery structure and retrieval paths of destination image using social network analysis. Journal of Travel Research, 57(5), 612-626. doi:10.1177/0047287517706262.

113. Wardi, Y., Abror, A. \&Trinanda, O. (2018). Halal tourism: antecedent of tourist's satisfaction and word of mouth (WOM). Asia Pacific Journal of Tourism Research, 23(5), 463-472. doi:10.1080/10941665.2018.1466816.

114. Wilson, J. A. (2017). Nation branding halal: challenges and opportunities. 1. International Halal Tourism Congress. Antalya, 20-21.

115. Xia, M., Zhang, Y. \& Zhang, C. (2018). A team-based approach to explore the effect of online experience on destination image: a smart phone user's perspective. Journal of Destination Marketing \& Management, 8, 259-270. doi:10.1016/j.jdmm.2017.05.002.

116. Xu, J., Chan, T. L. \& Pratt, S. (2018). Destination image of Taiwan from the perspective of Hong Kong residents: revisiting structural relationships between destination image attributes and behavioral intention. International Journal of Hospitality \& Tourism Administration, 19(3), 289-310. doi:10.1080/15256480.2017.1324339.

117. Xu, Z., Zhang, H., Zhang, C., Xu, M. \& Dong, N. (2019). Exploring the role of emotion in the relationship between museum image and tourists' behavioral intention: the case of three museums in Xi'an. Sustainability, 11(3), 559-579. doi:10.3390/su11030559.

118. Yagmur, Y., Ehtiyar, R., \& Aksu, A. (2019). Evaluation of halal tourism in terms of bibliometric characteristics. Journal of Islamic Marketing, doi:10.1108/JIMA-05-2019-0101.

119. Zailani, S., Omar, A. \&Kopong, S. (2011). An exploratory study on the factors influencing the non-compliance to halal among hoteliers in Malaysia. International Business Management, 5(1), 112.

120. Zhang, H., Fu, X., Cai, L. A. \& Lu, L. (2014). Destination image and tourist loyalty: a meta-analysis. Tourism Management, 40, 213-223. doi:10.1016/j.tourman.2013.06.006.

121. Zulkifli, W. S. W., Rahman, S. A., Awang, K. W. \& Man, Y. B. C. (2011). Developing the framework for halal friendly tourism in Malaysia. International Business Management, 5(6), 295-302. 


\section{JOURNAL OF TOURISM AND SERVICES}

Issue 21, volume 11, ISSN 1804-5650 (Online)

www.jots.cz

122. https://yigm.ktb.gov.tr/Eklenti/69320,turizmistatistikleri2019-4pdf.pdf?0,Retrieved August 12, 2020.

123. https://yigm.ktb.gov.tr/TR-9579/turizm-tesisleri.html,Retrieved August 17, 2020.

\section{Brief description of Authors:}

\section{Yenal Yağmur}

Siirt University, School of Tourism and Hotel Management, Recreation Management Programme, KezerCampus. Siirt, Turkey. yenal.yagmur@siirt.edu.tr

Mr. Yenal Yağmur works as an assistant professor at Siirt University, School of Tourism and Hotel Management in Siirt in TURKEY. He completed his PhD at Akdeniz University, Tourism Management Programme, in 2019. His specific areas of research are tourism and hospitality management, destination, and halal marketing. He has published conference papers and articles in tourism and hospitality journals.

\section{Akın Aksu}

Akdeniz University, Faculty of Tourism, Tourism Management Programme, Dumlupinar BoulevardCampus. Antalya-Turkey. aaksu@akdeniz.edu.tr

Mr. Akın Aksu works as a professor at Akdeniz University, Tourism Faculty, in Antalya in Turkey. He completed his PhD at Gazi University, Tourism Management Programme in 1999. His specific areas of research are management and organization, total quality management, and human resources management. He has published several international conference papers and refereed articles about tourism management at the tourism journals. He has published different books; Modern Management Techniques, Congress and Fair Management With Examples, My Career Guide, Solving of Problems at Touristic Establishments With examples, Halal Tourism. 